\title{
Pengaruh Gaya Kepemimpinan Kepala Sekolah dan Motivasi Kerja Guru Terhadap Kinerja Guru
}

\author{
Adang Rukmana \\ Madrasah Tsanawiyah Tanjungsari \\ adangrukmana@gmail.com
}

\begin{abstract}
ABSTRAK
Gaya kepemimpinan kepala sekolah, motivasi kerja guru secara simultan berpengaruh positif dan signifikan terhadap kinerja guru, dengan demikian hipotesis Ha diterima. Berdasarkan hasil pengolahan data dan hasil penelitian ternyata terdapat pengaruh antara gaya kepemimpinan kepala sekolah dan motivasi kerja terhadap kinerja guru madrasah sebesar 26,9\%. Maka dapat dikatakan bahwa semakin baik kualitas gaya kepemimpinan kepala sekolah dan motivasi kerja, maka akan semakin baik pula kinerja guru. Berdasarkan temuan itu, dapat disimpulkan bahwa: (1) Terdapat pengaruh yang positif dan signifikan antara gaya kepemimpinan kepala sekolah dengan empat sub-variabel terutama Gaya Executive dan Gaya Developer (2) Terdapat pengaruh yang positif dan signifikan antara gaya kepemimpinan kepala sekolah terhadap kinerja guru pada Madrasah Tsanawiyah/MTs (3) Terdapat pengaruh yang positif dan signifikan antara motivasi kerja terhadap kinerja guru, terutama motivasi finansial. (4) Terdapat pengaruh yang positif dan signifikan antara gaya kepemimpinan kepala sekolah dan motivasi kerja secara bersama-sama terhadap kinerja guru. (5) Upaya-upaya manajerial untuk memperbaiki gaya kepemimpinan kepala sekolah dan motivasi kerja serta kinerja guru yaitu dengan cara meningkatkan dimensi-dimensi yang menentukan variabel tersebut.
\end{abstract}

Kata kunci: gaya kepemimpinan kepala sekolah, motivasi kerja guru.

\begin{abstract}
The results of the analysis show the principal leadership style, teacher work motivation simultaneously significant and significant to teacher performance, thus hypothesis. Based on the results of data processing and research results there was an influence between the leadership style of principals and work motivation on the performance of madrasah teachers by 26.9\%. So it can be said the better the quality of leadership style of principal and work motivation, the better the performance of teachers. Based on these findings, it can be concluded: (1) There is a positive and significant influence between principal leadership style and four sub-variables on Executive Style and Developer Style (2) There is a positive and significant influence between principal leadership style on teacher performance Madrasah Tsanawiyah / MTSS (3) There is a positive and significant influence between work motivation on teacher performance, achievement of financial motivation. (4) There is a positive and significant influence between the principal's leadership style and the motivation of cooperation on teacher performance. (5) Managerial efforts to improve the principal's leadership style and work motivation and teacher performance by increasing the dimensions that determine these variables.
\end{abstract}

Key words: principal leadership style, teacher work motivation.

\section{PENDAHULUAN}

Dalam pendidikan dasar dan menengah, kepemimpinan dipegang oleh kepala sekolah, merupakan pemimpin yang mempunyai tugas dan tanggungjawab besar dalam segala aspek di dalamnya. (E.Mulyasa : 2011) berpendapat: terjadinya berbagai perubahan masyarakat, dan krisis multidimensi yang telah lama di Indonesia menyebabkan sulitnya menemukan sosok pemimpin ideal yang memiliki komitmen terhadap tugas dan tanggungjawabnya. Banyak pemimpin yang sebenarnya kurang layak mengemban amanah kepemimpinan. Demikian halnya dalam pendidikan, tidak sedikit adanya pemimpin pendidikan yang tidak efektif dan tidak memiliki visi dan misi yang jelas tentang sekolah yang dipimpinnya. Kepala sekolah sebagai penentu kebijakan harus mempunyai gaya kepemimpinan yang situasional yang bergantung pada situasi dan kondisi yang dihadapi sekolah dan memberi perhatian yang lebih berupa motivasi terhadap lingkungan sekolah dan orang orang yang menjadi warga sekolah terutama yang berhubungan dengan kinerja para guru. 
Kinerja guru yang baik merupakan harapan semua pihak, akan tetapi pada kenyataannya proses pembelajaran oleh guru Madrasah Tsanawiyah Swasta/MTsS setara dengan Sekolah Menengah Pertama (SMP) yang ada di Kecamatan Tanjungsari Sumedang belum maksimal sesuai yang diharapkan. Hal ini mengacu pada hasil penjajagan yang telah dilakukan, di mana ditemukan adanya fenomena antara lain: dalam perencanaan pembelajaran, dalam pelaksanaan pembelajaran dan dalam penilaian atau evaluasi pembelajaran. Dalam perencanaan pembelajaran, yaitu pembuatan administrasi guru (Rencana Program Pembelajaran/RPP, Program Tahunan, Progam Semester, Silabus, Nilai Kriteria Ketuntasan Minimal/KKM, dan Daftar Nilai), guru hanya menjiplak atau copy paste dari tahun-tahun sebelumnya atau dari orang lain. Guru membuat administrasi bukan sebagai acuan untuk melaksanakan pembelajaran di kelas, sehingga pelaksanaan pembelajaran di kelas relatif tidak terencana, akibatnya hasil belajar yang dicapai siswa belum menggembirakan.

Fenomena yang ada, dengan perencanaan pembelajaran kurang baik bisa berdampak pada nilai hasil ujian, salah satunya nilai Ujian Nasional (UN) yang dilaksanakan tiap tahun. Hasil UN pada Madrasah Tsanawiyah Swasta/MTsS di Kecamatan Tanjungsari tahun 2016 yang diikuti oleh 415 siswa, nilai rata-rata Ujian Nasional (UN) tiap mata pelajaran pada sebagai berikut mata pelajaran Bahasa Inggris: 58,0. Bahasa Indonesia 68,2. Ilmu Pengetahuan Alam 55,7, Matematika: 54,6. Apabila, mengacu kepada Standar Penilaian Pendidikan yang ditetapkan oleh Badan Standar Nasional Pendidikan (BSNP), yaitu nilai minimal kelulusan 55,0 tiap mata pelajaran. Maka siswa Madrasah Tsanawiyah/MTs Kecamatan Tanjungsari sebanyak $79 \%$ atau 327 siswa tidak lulus dan yang lulus hanya $21 \%$ atau 88 siswa. Fenomena hasil UN tersebut menjadi masalah baik bagi madrasah maupun kinerja guru Madrasah Tsanawiyah Swasta yang ada di Kecamatan Tanjungsari Kabupaten Sumedang.

Rendahnya kinerja guru bisa dilihat dari adanya gejala-gejala: seperti guru sering membolos/mangkir mengajar, guru yang masuk ke kelas tidak tepat waktu/terlambat. Guru yang mengajar tidak mempunyai persiapan mengajar atau persiapan mengajarnya kurang lengkap. Guru mengajar hanya sebuah rutinitas belaka tanpa adanya inovasi pengembangan lebih lanjut, bahkan adanya beberapa konsep metode mengajar yang baru seperti Lesson Study masih jarang diterapkan, dikarenakan metode tersebut dianggap kurang menarik bagi mereka. Prinsip oleh sebagian guru mengatakan yang penting kegiatan belajar mengajar sesuai dengan job dan jam yang telah ia penuhi sudah cukup bagi mereka. (Sumber: Pengawas Madrasah Kementrian Agama Kabupaten Sumedang).

Motivasi (motivation) pada dasarnya adalah motif (motive) yang berarti dorongan, sebab atau alasan seseorang melakukan sesuatu. Motivasi merupakan suatu kekuatan yang mendorong seseorang untuk melakukan suatu kegiatan (M.Sobry Sutikno: 2010). Sedangkan menurut Siagian, ( 2004:106 ) Motivasi kerja adalah keseluruhan proses pemberian motivasi bekerja kepada para bawahan sedemikian rupa, sehingga mereka mau bekerja dengan ikhlas demi tercapainya tujuan organisasi dengan efisien dan ekonomis. Dapat disimpulkan bahwa motivasi kerja adalah keseluruhan proses pemberian motif atau dorongan kerja pada para bawahan terutama para guru sebagai agen pendidikan dan pengajaran, agar tujuan pendidikan dan pengajaran dapat tercapai sesuai dengan rencana yang diharapkan.

Terciptanya kualitas kinerja guru yang profesional di sekolah membutuhkan dukungan peran kepala sekolah yang kompeten sebagai leader dan manager (Wahyudi, 2009: 29-36). Di satu sisi, kepala sekolah berperan sebagai pemimpin (Leader) yang memiliki visi ke masa depan yang jelas dan dapat diwujudkan serta mampu mendorong proses transparansi di sekolah. Di sisi lain, kepala sekolah berperan sebagai manajer, yang memiliki strategi-strategi yang efektif dan efisien untuk mengimplementasikan berbagai kebijakan dan keputusan yang telah ditetapkan.

Menurut Nasution (2004), kinerja guru dalam mengajar yaitu: (1) merencanakan pembelajaran, (2) melaksanakan pembelajaran dan (3) mengevaluasi pembelajaran. Kinerja guru antara lain dipengaruhi oleh motivasi yang berasal dari pemimpin seperti kepala sekolah yang menggerakan para gurunya untuk berkinerja baik. Namun demikian, bagaimana yang terjadi pada Madrasah Tsanawiyah Swasta/MTsS di Kecamatan Tanjungsari Sumedang, apakah kinerja guru yang kurang baik dan belum 
mencapai target/sasaran kinerja, ini dikarenakan motivasi kerja guru yang rendah dan juga karena gaya kepemimpinan kepala sekolah? Sampai seberapa besar pengaruhnya terhadap kinerja guru? Untuk mengetahui kondisi yang sebenarnya maka dilakukan penelitian dengan judul "Pengaruh Gaya Kepemimpinan Kepala Sekolah Dan Motivasi Kerja Guru Terhadap Kinerja Guru (Survey pada Madrasah Tsanawiyah Swasta/MTsS yang ada di Kecamatan Tanjungsari Sumedang)"

Berdasarkan latar belakang yang ada maka dapat diidentifikasikan masalahnya sebagai berikut:

1) Bagaimana pengaruh gaya kepemimpinan kepala sekolah terhadap motivasi kerja guru Madrasah Tsanawiyah/MTsS yang ada di Kecamatan Tanjungsari Sumedang.

2) Bagaimana pengaruh gaya kepemimpinan kepala sekolah terhadap kinerja guru Madrasah Tsanawiyah/MTsS yang ada di Kecamatan Tanjungsari Sumedang.

3) Bagaimana pengaruh motivasi kerja guru terhadap kinerja guru Madrasah Tsanawiyah/ MTsS yang ada di Kecamatan Tanjungsari Sumedang.

4) Bagaimana gaya kepemimpinan kepala sekolah dan motivasi kerja guru secara bersama-sama berpengaruh terhadap kinerja guru pada Madrasah Tsanawiyah/MTsS yang ada di Kecamatan Tanjungsari Sumedang.

5) Bagaimana upaya manajerial yang harus dilakukan untuk meningkatkan kinerja guru melalui perbaikan gaya kepemimpinan kepala sekolah dan motivasi kerja guru pada Madrasah Tsanawiyah/MTsS yang ada di Kecamatan Tanjungsari Sumedang.

Maksud penelitian ini adalah untuk mengetahui gambaran pengaruh gaya kepemimpinan kepala sekolah dan motivasi kerja guru terhadap kinerja guru di Madrasah Tsanawiyah Swasta/ MTs yang ada di Kecamatan Tanjungsari Sumedang.

Tujuan penelitian adalah untuk mengetahui tentang:

1) Pengaruh gaya kepemimpinan kepala sekolah terhadap motivasi kerja guru Madrasah Tsanawiyah/MTsS yang ada di Kecamatan Tanjungsari Sumedang.

2) Pengaruh gaya kepemimpinan kepala sekolah terhadap kinerja guru Madrasah Tsanawiyah/MTsS yang ada di Kecamatan Tanjungsari Sumedang.
3) Pengaruh motivasi kerja guru terhadap kinerja guru Madrasah Tsanawiyah/MTsS yang ada di Kecamatan Tanjungsari Sumedang.

4) Pengaruh gaya kepemimpinan kepala sekolah dan motivasi kerja secara bersama-sama terhadap kinerja guru Madrasah Tsanawiyah/MTsS yang ada di Kecamatan Tanjungsari Sumedang.

5) Upaya manajerial yang harus dilakukan untuk meningkatkan kinerja guru melalui perbaikan gaya kepemimpinan kepala sekolah dan motivasi kerja guru Madrasah Tsanawiyah/MTsS yang ada di Kecamatan Tanjungsari Sumedang.

\section{TINJAUAN PUSTAKA}

\section{Gaya Kepemimpinan}

Gaya kepemimpinan merupakan hasil yang akan dicapai oleh seorang pemimpin yang sukses. Kepemimpinan bukanlah berarti seorang administrator harus menjadi pemimpin atau seorang kepala harus berubah menjadi pemimpin, tetapi yang terpenting adalah bagaimana Kepala Sekolah mempengaruhi semua elemen yang ada di sekolah dalam mencapai tujuan. Oleh karena itu, gaya kepemimpinan kepala sekolah yang efektif adalah pemimpin yang dapat merasakan apa yang diperlukan dengan memberikan motivasi agar para guru dapat berkinerja dengan baik dalam mencapai tujuan visi dan misi sekolah.

Menurut Bill Woods (dalam Syaiful : 2008), ada tiga gaya kepemimpinan yaitu:

1) Otokratis

Kepemimpinan otokratis adalah pemimpin yang membuat keputusannya sendiri. Pemimpin memikul tanggung jawab dan wewenang penuh. Kepemimpinan otokratis merupakan gaya kepemimpinan yang semua kendali dipegang oleh pemimpinnya. Pemimpin yang menggunakan gaya ini cenderung bersikap sewenang-wenang terhadap bawahannya. Ciri-ciri pemimpin yang otokrasi adalah:

a) Menganggap organisasi yang dipimpinnya sebagai milik pribadi

b) Menganggap bawahan sebagai alat semata

c) Tidak mau menerima pendapat, saran dan kritik

d) Cara menggerakan bawahan dengan pendekatan paksaan dan bersifat mencari kesalahan/menghukum. 
2) Demokratis

Menurut Ngalim (2002) kepemimpinan demokrasi atau partisipatif adalah pemimpin yang melakukan konsultasi dengan kelompok mengenai masalah yang menarik perhatian mereka di mana mereka dapat menyumbangkan sesuatu. Menurut penulis gaya kepemimpinan demokratis adalah gaya kepemimpinan terbaik sehingga ada komunikasi baik antara atasan dengan bawahan.

\section{3) Laizes-faire (Kendali bebas)}

Menurut Syaiful (2008) kepemimpinan ini adalah pemimpin yang memberi kekuasaan pada bawahan, kelompok dapat mengembangkan sasarannya sendiri dan memecahkan masalahnya sendiri, tidak ada pengarahan dari pemimpin. Gaya ini biasanya tidak berguna tetapi dapat menjadi efektif dalam kelompok profesional yang termotivasi tinggi. Pemimpin yang menggunakan gaya kepemimpinan ini cenderung tidak mempunyai prinsip dan tidak kreatif karena semua kendali diberikan penuh kepada bawahan. Jadi tidak ada arahan dari pemimpin.

Dalam situasi yang tidak tepat, gaya kepemimpinan tersebut menjadi kurang efektif, tetapi dalam situasi yang tepat ia menjadi sangat efektif. Gaya kepemimpinan yang mungkin ideal menggunakan semua gaya yang ada sebaik mungkin pada situasi yang mendukung dan memenuhi kebutuhan kinerja kepemimpinan itu sendiri. Hal ini berarti situasilah yang mungkin menentukan gaya apa yang digunakan, karenanya tidak mungkin menerapkan satu gaya secara efisien. (E. Mulyasa, 2005:138).

Gaya kepemimpinan merupakan pola perilaku seorang pemimpin yang khas pada saat mempengaruhi anak buahnya, apa yang dipilih oleh pemimpin untuk dikerjakan, cara pemimpin bertindak dalam mempengaruhi anggota kelompok membentuk gaya kepemimpinannya. Pola perilaku pemimpin terlihat pada saat mereka memulai memberikan tanggapan terhadap situasi, dan pola ini akan terlihat jelas pada saat pemimpin memberikan tanggapan yang sama pada situasi yang sama. Dari pola perilaku ini akan membentuk suatu kebiasaan pemimpin yang dapat diperkirakan oleh bawahannya (E.Mulyasa, 2005:108).
Dilihat dari segi efektif dan tidak efektif, bahwa gaya kepemimpinan dikelompokkan menjadi 2 (dua) kelompok yaitu: (1) Gaya efektif, terdiri dari gaya executif, gaya developer, gaya benevolent authocrat dan gaya birokrat. (2) gaya tidak efektif, terdiri dari gaya compromiser, gaya missionary, gaya autocrat dan gaya deserter (E. Mulyasa, 2005:138).

\section{1) Gaya Efektif}

a) Gaya executive, gaya ini menunjukan adanya perhatian baik kepada tugas maupun kepada hubungan kerja dalam kelompok. Pimpinan berusaha memotivasi anggota dan menetapkan standar kerja yang tinggi serta mau mengerti perbedaan individu dan menempatkan individu sebagai manusia.

b) Gaya developer, gaya ini memberikan perhatian yang cukup tinggi terhadap hubungan kerja dalam kelompok dan perhatian minimum terhadap tugas pekerjaan. Pimpinan yang menganut gaya ini sangat memperhatikan pengembangan individu.

c) Gaya benevolent autokrat, gaya ini memberikan perhatian yang tinggi terhadap tugas, dan rendah dalam hubungan kerja. Pemimpin yang menganut gaya ini mengetahui secara tepat apa yang ia inginkan dan bagaimana memperoleh yang diinginkan tersebut tanpa menyebabkan ketidakseganan di pihak lain.

d) Gaya birokrat, gaya ini memberikan perhatian yang rendah terhadap tugas maupun terhadap hubungan. Pemimpin yang menganut gaya ini menerima setiap peraturan dan berusaha memeliharanya dan melaksanakannya.

2) Gaya tidak efektif

a) Gaya compromiser, gaya ini memberi perhatian yang tinggi pada tugas maupun pada hubungan kerja. Pemimpin yang menganut gaya ini merupakan pembuat keputusan yang tidak efektif dan sering menemui hambatan dan masalah.

b) Gaya Missionary, pada gaya ini memberi perhatian yang tinggi pada hubungan kerja dan rendah pada tugas. Pemimpin yang menganut gaya ini hanya tertarik pada keharmonisan dan tidak bersedia mengontrol hubungan meskipun tujuan tidak tercapai

c) Gaya Autocrat, gaya ini memberi perhatian yang tinggi pada tugas dan rendah pada hubungan. Pemimpin yang menganut gaya ini 
selalu menetapkan kebijaksanaan dan keputusan sendiri.

d) Gaya deserter, gaya ini memberi pehatian yang rendah pada tugas dan hubungan kerja. Pemimpin yang menganut gaya ini hanya mau memberikan dukungan dan memberikan struktur yang jelas serta tanggung jawab, hanya pada waktu dibutuhkan.

Kepemimpinan Kepala Sekolah menurut Paul Hersey dan Blandhard dalam Permadi (2001:78) menyatakan ada empat (4) gaya kepemimpinan kepala sekolah diantaranya:

1) Gaya instruksi atau mengarahkan seperti memberikan instruksi kepada guru dan memberikan instruksi kepada siswa dalam proses pembelajaran

2) Gaya konsultasi atau bermusyawarah seperti berkonsultasi dengan guru dalam memecahkan permasalahan sekolah dan bermusyawarah untuk mendapatkan mufakat

3) Gaya partisipatif atau demokratis seperti bersifat partisipasi dan bersifat demokratis

4) Gaya delegasi atau pelimpahan wewenang seperti memberikan wewenang pengajaran dan memberikan wewenang mengenai penyikapan terhadap siswa.

Gaya kepemimpinan seorang kepala sekolah dapat mempengaruhi beberapa aspek (Wahjosumidjo, 2005: 83), diantaranya:

1) Gaya kepemimpinan mempengaruhi efektivitas kerja di mana ciri-ciri seorang pemimpin secara fisik, pengetahuan intelektualitasnya, penampilan, pribadi, kedinamisan, percaya diri dan kekuasaan, menjadi hal yang harus dimiliki oleh seseorang yang akan menjadi pemimpin (Dasim Budimansyah, 2002:5).

Dengan demikian akan menjadi otoritas tersendiri terhadap orang lain, loyalitas terhadap perserikatan (perkumpulan). Semua unsur tersebut bukanlah hal yang mutlak yang harus dimiliki oleh seorang kepala sekolah. Keterbatasan Kepala Sekolah akan semua unsur tadi akan menjadi hambatan, tetapi hal yang penting yang harus diperhatikan adalah gaya kepemimpinan Kepala Sekolah yang dihasilkan dari kombinasi kekuatan yang ada dan menutupi kekurangan.

2) Gaya kepemimpinan dapat mempengaruhi sikap tertentu yang dilakukan oleh bawahannya. Ini berakibat pada perilaku bawahan yang akan terpengaruhi oleh kebijakan yang dikeluarkan oleh Kepala Sekolah. Akibatnya semua perilaku, yang dalam hal ini terjadi di Sekolah, sedikit besar akan mengikuti kehendak Kepala Sekolah sesuai dengan gaya yang ditimbulkan (Ahmad Tafsir, 1992: 92).

Untuk memperindah gaya yang diperankan, maka Kepala Sekolah harus mempunyai pendekatan yang khusus supaya mampu menampilkan gaya yang halus dan dapat diterima oleh semua pihak.

3) Gaya kepemimpinan mempengaruhi hasil kerja seorang bawahannya. Percepatan kerja atau sebaliknya adalah hasil umpan balik dari sebuah gaya perintah dan seorang pemimpin. Oleh karena itu, seorang pemimpin harus bisa mengendalika gayanya supaya dapat merealisasikan hasil kerja yang sesuai dengan keinginanya.

Dalam penelitian ini yang menjadi tolok ukur Gaya Kepemimpinan Kepala Sekolah yang dikemukakan oleh E. Mulyasa, 2005:138.

\section{Konsep Motivasi Kerja Guru}

Motivasi kerja guru adalah keseluruhan proses pemberian motif atau dorongan kerja para guru sebagai agen pendidikan dan pengajaran, agar tujuan pendidikan dan pengajaran dapat tercapai sesuai dengan rencana. Dengan demikian, Motivasi kerja guru adalah suatu proses yang dilakukan untuk menggerakkan guru agar perilaku mereka dapat diarahkan pada upaya-upaya yang nyata untuk mencapai tujuan yang telah ditetapkan.

Yunus (2007:45) mengemukakan sejumlah faktor dalam pekerjaan yang mempengaruhi motivasi kerja guru sebagai berikut:

1) Rasa aman (security), yaitu adanya kepastian untuk memperoleh pekerjaan tetap, memangku jabatan di organisasi selama mungkin seperti yang mereka harapkan.

2) Kesempatan untuk maju, yaitu adanya kemungkinan untuk maju, naik tingkat, memperoleh kedudukan dan keahlian.

3) Tipe pekerjaan, yaitu adanya pekerjaan yang sesuai dengan latar belakang pendidikan, pengalaman, bakat, dan minat.

4) Nama baik tempat bekerja, yaitu sekolah yang memberikan kebanggaan karyawan bila bekerja di perusahaan atau sekolah tersebut. 
5) Rekan kerja yaitu rekan kerja yang sepaham, yang cocok untuk bekerja sama.

6) Upah, yaitu penghasilan yang diterima.

7) Penyelia, yaitu pemimpin atau atasan yang mempunyai hubungan baik dengan bawahannya, mengenal bawahannya, dan mempertimbangkan pendapat-pendapat yang dikemukakan oleh bawahannya.

8) Jam kerja, yaitu jam kerja yang teratur atau tertentu dalam sehari.

9) Kondisi kerja, yaitu seperti kebersihan tempat kerja, suhu, ruangan kerja, ventilasi, kegaduhan suara, bau dan sebagainya.

10)Fasilitas, yaitu kesempatan cuti, jaminan kesehatan, pengobatan dan sebagainya.

Selanjutnya, faktor yang tidak kalah penting dalam upaya mendorong motivasi kerja guru. Gitosudarmo dan Mulyono (1999), mengemukakan bahwa motivasi atau dorongan kepada karyawan untuk bersedia bekerja bersama demi tercapainya tujuan bersama, terdapat dua macam, yaitu:

1) Motivasi finansial, yaitu dorongan yang dilakukan dengan memberikan imbalan finansial seperti: gaji, tunjangan struktural, tunjangan fungsional, tunjangan keluarga (suami/istri, anak), tunjangan hari raya, pembayaran insentif, upah lembur dan uang.

2) Motivasi non finansial, yaitu dorongan yang diwujudkan tidak dalam bentuk finansial/uang seperti: cuti kerja, kenaikan pangkat, tanda penghargaan, pendidikan dan pelatihan dan promosi jabatan.

Kepala sekolah perlu meningkatkan kemampuan dan keterampilan para pelaksana pendidikan. Sebagai pemimpin dalam lembaga pendidikan hendaknya kepala sekolah memiliki pengetahuan yang luas dan keterampilan kepemimpinan. Hal itu perlu dimiliki agar mampu mengendalikan, mempengaruhi dan mendorong bawahannya dalam menjalankan tugas dengan jujur, tanggung jawab, efektif dan efisien.

Dalam penelitian ini yang menjadi tolok ukur motivasi kerja adalah motivasi finansial dan motivasi non finansial yang dikemukakan oleh Gitosudarmo dan Mulyono (1999).

\section{Pengertian Kinerja Guru}

Kinerja berasal dari pengertian performance, ada pula yang memberikan pengertian performance sebagai hasil kerja atau prestasi kerja namun sebenarnya kinerja mempunyai makna yang lebih luas bukan hanya hasil kerja tetapi termasuk bagaimana proses pekerjaan berlangsung. (dalam Wibowo, 2011:7)

Malayu S.P Hasibuan (2001: 94) mendefinisikan kinerja atau prestasi kerja adalah suatu hasil kerja yang dicapai seseorang dalam melaksanakan tugas tugas yang dibebankan kepadanya yang didasarkan pada kecakapan, pengalaman dan kesungguhan serta waktu. Undang-Undang Republik Indonesia Nomor 20 Tahun 2003 tentang Sistem Pendidikan Nasional disebutkan bahwa guru adalah: Tenaga pengajar merupakan tenaga pendidik yang khususnya diangkat dengan tugas utama mengajar, pada jenjang pendidikan dasar dan menengah disebut dengan guru dan pada jenjang pendidikan tinggi disebut dosen. Jadi yang dimaksud dengan guru adalah orang yang pekerjaannya dan profesinya mengajar di sekolah jenjang pendidikan dasar dan menengah.

Kinerja guru menurut Casseter dalam E.Mulyasa (2003: 45) meliputi beberapa indikator yaitu:

1. Karakteristik individu seperti kepribadian dan dedikasi

2. Proses seperti pengembangan profesi

3. Hasil seperti kemampuan mengajar

Dari beberapa pengertian tersebut dapat disimpulkan bahwa kinerja merupakan hasil kerja kualitas maupun kuantitas yang dicapai oleh seseorang atau sekelompok guna melaksanakan tugas kerja sesuai dengan wewenang dan tanggung jawab dalam rangka mencapai tujuan organisasi.

Berdasarkan pendapat para ahli tersebut maka dapat dikatakan bahwa yang dimaksud dengan kinerja guru atau prestasi kerja (performance) guru adalah hasil yang dicapai oleh guru dalam melaksanakan tugas-tugasnya yang dibebankan kepadanya yang didasarkan atas kecakapan, pengalaman dan kesungguhan serta waktu dengan output yang dihasilkan yang tercermin, baik kualitas maupun kuantitasnya.

Kinerja guru, merupakan perpaduan antara kemampuan seorang guru dan usahanya yang kemudian menghasilkan apa yang dikerjakan dalam bidang kependidikan. Dalam melaksanakan suatu pekerjaan seorang guru atau karyawan tidak terlepas dipengaruhi oleh dua faktor, yaitu: faktor internal dan eksternal. Faktor Internal dapat diartikan sebagai 
segala bentuk usaha yang berasal dari dalam diri sendiri (guru) yang dapat memberikan dorongan untuk melaksanakan pekerjaan degan baik yang meliputi kemampuan, pengetahuan, dan motivasi diri dalam bekerja. Faktor eksternal adalah segala sesuatu yang berasal dari luar usaha guru itu sendiri, seperti: fasilitas, gaya kepemimpinan Kepala Sekolah, situasi kerja, sistem pengelolaan dan lain sebagainya.

Menurut Departemen Pendidikan Nasional (2005:15) bahwa indikator kinerja guru meliputi kegiatan-kegiatan sebagai berikut:

1) Merencanakan pembelajaran

a) Membuat perangkat kegiatan pembelajaran

b) Menentukan materi sesuai dengan kompetensi yang telah ditentukan

c) Menentukan metode pembelajaran yang sesuai

d) Menentukan media pembelajaran

2) Melaksanakan kegiatan pembelajaran

a) Kegiatan pendahuluan

b) Kegiatan inti

c) Kegiatan penutup

3) Mengevaluasi hasil pembelajaran

a) Menyusun soal/perangkat penilaian sesuai dengan indikator/kriteria unjuk kerja yang telah ditentukan

b) Melaksanakan penilaian

c) Menganalisis hasil penilaian (berdasarkan tingkat kesukaran, daya pembeda, validitasi dan reliabilitas)

d) Menyimpulkan hasil penilaian secara jelas dan logis (misalnya interpretasi kecenderungan hasil penilaian, tingkat pencapaian siswa)

e) Menyusun laporan hasil penilaian

f) Memperbaiki soal/perangkat penilaian.

4) Tindak lanjut hasil penilaian prestasi belajar siswa

a) Menyusun program tindak lanjut penilaian

b) Melaksanakan tindak lanjut

c) Mengevaluasi hasil tindak lanjut penilaian.

Dalam penelitian ini yang menjadi tolok ukur kinerja guru adalah menurut Dinas Pendidikan Provinsi Jawa Barat (2005:15).

\section{KERANGKA PEMIKIRAN}

Salah satu tugas kepala sekolah sebagai pemimpin pendidikan yaitu memimpin staff (guru-guru, tata usaha dan pesuruh) membina kerjasama yang harmonis antar anggota staff sehingga dapat membangkitkan semangat kerja, motivasi kerja bagi staff yang dipimpin serta menciptakan budaya kerja yang kondusif. Kepemimpinan yang baik, kerjasama yang harmonis serta suasana yang kondusif menjamin staf menjadi senang untuk melaksanakan tugas dengan sebaik-baiknya. Di samping itu, kepemimpinan kepala sekolah merupakan kunci proses pemberdayaan kegiatan pendidikan di sekolah. Unsur kepemimpinan kepala sekolah adalah pengaruh yang dimilikinya dan kemampuan menggunakan pengaruh tersebut bagi orang yang hendak dipengaruhinya yaitu khususnya dalam penelitian ini para guru agar berkinerja baik.

Tolak ukur dari kinerja guru sendiri meliputi aktivitas yang berkaitan dengan perencanaan pengajaran, pelaksanaan proses pengajaran, pelaksanaan penilaian pengajaran dan tindak lanjut penilaian. Motivasi kerja guru sebagai perangsang keinginan dan daya gerak yang menyebabkan seorang guru bersemangat dalam mengajar. Guru yang bersemangat dalam mengajar terlihat dalam ketekunannya ketika melaksanakan tugas, ulet, minat yang tinggi dalam memecahkan permasalahan, kreatif dan sebagainya. Hal - hal tersebut berdampak pada kinerja guru.

\section{METODOLOGI PENELITIAN}

Objek dari penelitian yang berjudul "Pengaruh Gaya Kepemimpinan Kepala Sekolah Dan Motivasi Kerja Guru Terhadap Kinerja Guru" adalah mengkorelasikan variabel bebas yaitu Gaya kepemimpinan Kepala Sekolah (X1), Motivasi Kerja Guru (X2) dan variabel terikat yaitu Kinerja Guru (Y). Objek yang diteliti, yaitu guru-guru pada Madrasah Tsanawiyah Swasta/MTsS yang ada di Kecamatan Tanjungsari Kabupaten Sumedang. Dalam penelitian ini menggunakan jenis data kualitatif untuk data yang bersifat kualitatif juga pendekatan kuantitatif yang dipergunakan untuk data kuantitatif. Penelitian kualitatif ditujukan untuk mendeskripsikan pengaruh gaya kepemimpinan kepala sekolah dan motivasi kerja terhadap kinerja guru. Sedangkan kuantitatif dimaksudkan untuk menghitung pengaruh gaya kepemimpinan dan motivasi guru terhadap kinerja guru secara statistik. Informasi dikumpulkan langsung di tempat kejadian secara empirik, dengan tujuan mengetahui 
pendapat tentang objek yang sedang diteliti. Data diperoleh dari sumber data pada Madrasah Tsanawiyah Swasta/MTsS di Kecamatan Tanjungsari Sumedang. Pengujian hipotesis tehnik analisis dengan menggunakan korelasi. Sesuai dengan hipotesis yang diajukan, maka dalam pengujiannya dilakukan terlebih dahulu uji validitas dan realibilitas. Kemudian data diolah melalui analisis deskriftif dan analisis jalur (Path Analysis) untuk uji hipotesisnya.

Dalam penelitian ini menggunakan sampel jenuh, menurut Sugiyono (2016:85) sampel jenuh adalah teknik penentuan sampel bila semua anggota populasi digunakan sebagai sampel, istilah lain sampel jenuh adalah sensus. Penelitian dilaksanakan di Madrasah Tsanawiyah Swasta Kecamatan Tanjungsari Kabupaten Sumedang dengan jumlah 3 variabel, peneliti menentukan jumlah sensus sebanyak 120 orang, yang terbagi pada dua wilayah. Pertama wilayah perkotaan yang terdiri dari tiga MTs, Kedua wilayah pedesaan terdiri dari tiga MTs,

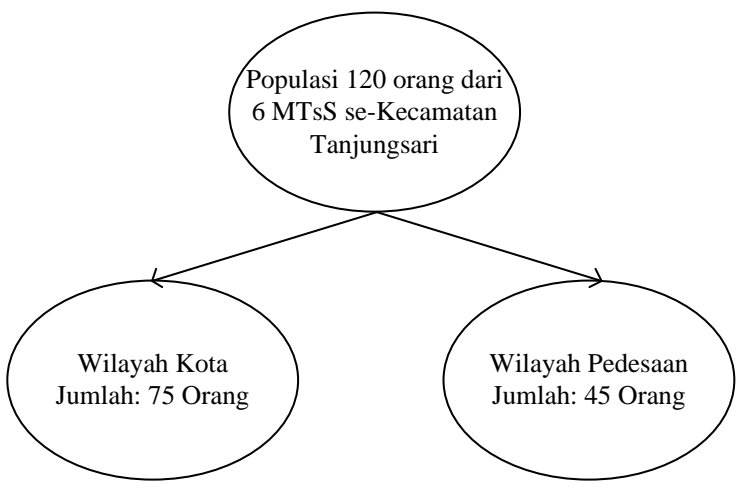

Gambar 1. Jumlah Responden Berdasarkan Wilayah

\section{HASIL DAN PEMBAHASAN}

\section{Deskripsi Gaya Kepemimpinan Kepala Sekolah pada MTsS Perkotaan di Kecamatan Tanjungsari}

Gaya kepemimpinan kepala sekolah MTsS Perkotaan Tanjungsari adalah baik yaitu sebesar $78,24 \%$ dari seluruh pernyataan pada variabel tersebut. Indikator dengan nilai persentase tertinggi ada pada item ke-1, yaitu Kepala sekolah selalu memperhatikan pada tugas pokok dan fungsi kerja guru. Persentase dari indikator ini sebesar $92,8 \%$. Sedangkan persentase terendah terdapat pada item ke-13, yaitu Kepala sekolah menggunakan otoritas dalam menetapkan tujuan sekolah, sebesar 73,6\%. Dari data di atas Gaya Kepemimpinan Kepala Sekolah dalam dimensi Gaya Executive mendapatkan nilai rata-rata tertinngi yaitu dengan nilai rata-rata $80,88 \%$, Gaya ini menunjukan adanya perhatian baik kepada tugas maupun kepada hubungan kerja dalam kelompok. Pimpinan berusaha memotivasi anggota dan menetapkan standar kerja yang tinggi serta mau mengerti perbedaan individu dan menempatkan individu sebagai manusia. Sedangkan nilai rata-rata terkecil yaitu dalam dimensi Gaya Kepemimpinan Birokrat sebesar $76,25 \%$. gaya ini memberikan perhatian yang rendah terhadap tugas maupun terhadap hubungan. Pemimpin yang menganut gaya ini menerima setiap peraturan dan berusaha memeliharanya dan melaksanakannya.

Oleh karena itu Gaya Kepemimpinan Executive kecenderungan banyak dipakai oleh para kepala sekolah Madrasah Tsanawiyah Swasta/ MTsS perkotaan di Kecamatan Tanjungsari Sumedang, serta perlu dipertahankan atau diperbaiki apabila dianggap paling baik. Untuk gaya kepemimpinan Birokrat perlu diperbaiki dan dapat dipakai yang disesuaikan dengan situasi dan kondisi masing-masing sekolah..

\section{Deskripsi Gaya Kepemimpinan Kepala Sekolah Madrasah Tsanawiyah Swasta/MTsS Pedesaan di Kecamatan Tanjungsari}

Gaya kepemimpinan kepala sekolah pada MTsS desa adalah baik yaitu sebesar $81,62 \%$ dari seluruh pernyataan variabel tersebut. Indikator dengan nilai persentase tertinggi ada pada item ke-20, yaitu Kepala sekolah mengambil keputusan secara cepat berdasarkan pertimbangan yang matang. Persentase dari indikator ini sebesar 90,22\%. Sedangkan persentase terendah terdapat pada item ke-13, yaitu Kepala sekolah menggunakan otoritas dalam menetapkan tujuan sekolah, sebesar 73,78\%. Kepemimpinan Kepala Sekolah Madrasah Tsanawiyah Swasta/MTsS dalam dimensi Gaya Benevolent Authocrat mendapatkan nilai rata-rata tertinngi yaitu dengan nilai $86,11 \%$, Gaya ini memberikan perhatian yang tinggi terhadap tugas, dan rendah dalam hubungan kerja. Pemimpin yang menganut gaya ini mengetahui secara tepat apa yang ia inginkan dan bagaimana memperoleh yang 
diinginkan tersebut tanpa menyebabkan ketidakseganan di pihak lain. Sedangkan nilai rata-rata terkecil yaitu dalam dimensi Gaya Kepemimpinan Birokrat sebesar 75,82 \%. Gaya ini memberikan perhatian yang rendah terhadap tugas maupun terhadap hubungan. Pemimpin yang menganut gaya ini menerima setiap peraturan dan berusaha memeliharanya dan melaksanakannya. Gaya Kepemimpinan Authocrat kecenderungan banyak dipakai oleh para kepala sekolah Madrasah Tsanawiyah Swasta/MTsS Pedesaan di Kecamatan Tanjungsari Sumedang, serta perlu dipertahankan apabila dianggap baik.

\section{Deskripsi Motivasi Kerja Guru Madrasah Tsanawiyah Perkotaan Tanjungsari}

Variabel motivasi kerja adalah baik yaitu sebesar $79,31 \%$ dari seluruh pernyataan pada variabel tersebut. Indikator dengan nilai persentase tertinggi ada pada item ke-3, yaitu pemberian tunjangan profesi guru/tunjangan kinerja sangat membantu meningkatkan kesejahteraan. Persentase dari indikator ini sebesar $85,6 \%$. Sedangkan persentase terendah terdapat pada item ke-10, yaitu Bila memiliki prestasi kerja, kepala sekolah memberikan promosi jabatan, sebesar75,2 \%. Dari data di atas dimensi motivasi finansial mendapatkan jumlah nilai rata-rata tertinngi yaitu dengan nilai 80,26\%, Motivasi finansial, merupakan dorongan yang dilakukan dengan memberikan imbalan finansial seperti: gaji, tunjangan struktural, tunjangan fungsional, tunjangan keluarga (suami/istri,anak), tunjangan hari raya, pembayaran insentif, upah lembur dan uang.

Sedangkan jumlah nilai terkecil yaitu dalam dimensi motivasi non finansial sebanyak 292,3 atau nilai rata-rata $77,89 \%$. Motivasi non finansial, adalah dorongan yang diwujudkan tidak dalam bentuk finansial/uang, seperti: cuti kerja, kenaikan pangkat, tanda penghargaan, pendidikan dan pelatihan dan promosi jabatan. Oleh karena itu kecenderungan Motivasi Kerja Guru Madrasah Tsanawiyah Swasta/MTsS Perkotaan yang ada di Kecamatan Tanjungsari Sumedang sangat dipengaruhi oleh motivasi finansial dan kecenderungan sedikit motivasi kerja guru yang bersifat non finansial.

\section{Deskripsi Motivasi Kerja Guru pada MTsS Pedesaan di Kecamatan Tanjungsari Kabupaten Sumedang}

Motivasi kerja adalah baik yaitu sebesar $82,04 \%$ dari seluruh pernyataan pada variabel tersebut. Indikator dengan nilai persentase tertinggi ada pada item ke-9, yaitu Kepala sekolah selalu memberikan kesempatan kepada guru untuk mengikuti pelatihan/pendidikan.. Persentase dari indikator ini sebesar $89,78 \%$. Sedangkan persentase terendah terdapat pada item ke-1, yaitu Gaji yang diterima sesuai dengan beban kerja yang diemban, sebesar $66,67 \%$ dengan kriteria cukup baik.

Dimensi motivasi non finansial mendapatkan jumlah nilai tertinngi yaitu dengan jumlah 1846 atau nilai rata-rata $86 \%$, Motivasi non finansial, adalah dorongan yang diwujudkan tidak dalam bentuk finansial/uang seperti: cuti kerja, kenaikan pangkat, tanda penghargaan, pendidikan dan pelatihan dan promosi jabatan. Sedangkan jumlah nilai terkecil yaitu dalam dimensi Motivasi Finansial sebanyak 1072 atau nilai rata-rata $79,40 \%$. Motivasi finansial, merupakan dorongan yang dilakukan dengan memberikan imbalan finansial seperti: gaji, tunjangan struktural, tunjangan fungsional, tunjangan keluarga (suami/istri,anak), tunjangan hari raya, pembayaran insentif, upah lembur dan uang.

Oleh karena itu kecenderungan Motivasi Kerja Guru Madrasah Tsanawiyah Swasta/MTsS Pedesaan yang ada di Kecamatan Tanjungsari Sumedang sangat dipengaruhi oleh motivasi non finansial, hal ini mungkin disebabkan berbagai faktor seperti: Biaya hidup di pedesaan rendah, tradisi gotong royong masih melekat, beras dan sayuran tersedia, sumber daya alam seperti air sudah tersedia, dan lain sebagainya. Kecenderungan yang lain motivasi kerja guru Madrasah Tsanawiyah Swasta/MTsS Pedesaan bersifat finansial mungkin dirasakan kurang berpengaruh, yang diperlukan adalah status sebagai guru dan mempunyai pekerjaan tetap meskipun finansial/gaji nya sedikit atau rendah.

\section{Deskripsi Kinerja Guru pada MTsS Perkotaan Kecamatan Tanjungsari Sumedang,}

Vriabel kinerja guru adalah baik yaitu sebesar $79,98 \%$ dari seluruh pernyataan pada variabel tersebut. Indikator dengan nilai persentase 
tertinggi ada pada item ke-2, Saya dalam menyusun perangkat pembelajaran selalu mencari masukan-masukan dari pihak lain, persentase sebesar 89,07 \%.. Sedangkan persentase terendah terdapat pada item ke-28, yaitu pernyataan Saya jarang melaksanakan penilaian dengan berbagai teknik dan jenis penilaian, selain penilaian formal yang dilaksanakan sekolah, dan mengumumkan hasil serta implikasinya kepada peserta didik, tentang tingkat pemahaman terhadap materi pembelajaran yang telah dan akan dipelajari sesuai indikator, persentase sebesar 69,87\%. Dari data di atas tentang Kinerja Guru Madrasah Tsanawiyah Swasta perkotaan dalam dimensi mengevaluasi hasil pembelajaran mendapatkan nilai tertinggi yaitu dengan jumlah 616 atau nilai rata-rata $82,40 \%$ sebanyak dua item pernyataan. Adapun indkatornya sebagai berikut: Menyusun soal/perangkat penilaian sesuai dengan indikator/kriteria unjuk kerja yang telah ditentukan, Melaksanakan penilaian, Menganalisis hasil penilaian (berdasarkan tingkat kesukaran, daya pembeda, validitasi dan reliabilitas), Menyimpulkan hasil penilaian secara jelas dan logis (misalnya interpretasi kecenderungan hasil penilaian, tingkat pencapaian siswa), Menyusun laporan hasil penilaian, Memperbaiki soal/perangkat penilaian. Dimensi ini perlu dipertahankan dan ditingkatkan dalam kinerja guru Madrasah Tsanawiyah perkotaan di Kecamatan Tanjunsari-Sumedang.

Sedangkan jumlah nilai terkecil yaitu dalam dimensi tindak lanjut hasil penilaian pembelajaran sebanyak 1758 atau nilai rata-rata 78,13\% dengan 6 item pernyataan. Indikator tindak lanjut hasil penilaian prestasi belajar siswa adalah sebagai berikut: Menyusun program tindak lanjut penilaian, Melaksanakan tindak lanjut, Mengevaluasi hasil tindak lanjut penilaian. Dimensi ini perlu diperbaiki dalam kinerja guru Madrasah Tsanawiyah perkotaan di Kecamatan Tanjungsari Kabupaten Sumedang.

Oleh karena itu, kecenderungan guru-guru Madrasah Tsanawiyah/MTs perkotaan yang ada di Kecamatan Tanjungsari telah melaksanakan evaluasi hasil pembelajaran dengan baik, tetapi perlu ditingkatkan lagi. Dilain pihak ada kecenderungan lain, guru-guru Madrasah Tsanawiyah Swasta yang ada di perkotaan tidak melaksanakan tindak lanjut hasil evaluasi pembelajaran secara maksimal, seperti siswa yang nilai kurang tidak diadakan remidial atau her, siswa yang belum tuntas dalam pembelajarannya tidak dituntaskan dan lain sebagainya, termasuk dalam proses pembelajarannya masih perlu diperbaiki atau ditingkatkan.

\section{Deskripsi Kinerja Guru pada MTsS Pedesaan Kecamatan Tanjungsari Sumedang}

Variabel kinerja guru MTsS desa adalah sangat baik yaitu sebesar $84,8 \%$ dari seluruh pernyataan pada variabel tersebut. Indikator dengan nilai persentase tertinggi ada pada 3 item yaitu item ke-10 yaitu pernyataan "saya menyampaikan tujuan pembelajaran melalui media pembelajaran sesuai dengan cakupan materi yang akan dijelaskan". Item ke 14 yaitu pernyataan "saya selalu menyapa peserta didik secara aktif setiap pembelajaran dalam kegiatan pendahuluan" dan item ke-23 yaitu pernyataan "saya melakukan penilaian dan atau refleksi terhadap kegiatan yang sudah dilaksanakan secara konsisten dan terpogram", persentase pada 3 item tersebut masing-masing sama sebesar 91,11\% dengan kriteria sangat baik.. Sedangkan persentase terendah terdapat pada item ke-1, yaitu pernyataan Saya mempunyai kepercayaan tinggi untuk mengembangkan perangkat pembelajaran, persentase sebesar 70,22 \% dengan kriteria baik. Kinerja Guru Madrasah Tsanawiyah Swasta pedesaan dalam dimensi merencanakan pembelajaran mendapatkan nilai terendah yaitu dengan jumlah 2401 atau rata-rata 82,08\%, adapun indikator merencanakan pembelajaran, diantaranya sebagai berikut: Membuat perangkat kegiatan pembelajaran, Menentukan materi sesuai dengan kompetensi yang telah ditentukan, Menentukan metode pembelajaran yang sesuai, Menentukan media pembelajaran. Dimensi ini perlu diperbaiki dalam kinerja guru Madrasah Tsanawiyah Swasta pedesaan.

Sedangkan jumlah nilai tertinggi yaitu dalam dimensi mengevaluasi hasil pembelajaran sebanyak 401 atau rata $89,45 \%$. Dengan indikatornya sebagai berikut: Menyusun soal/perangkat penilaian sesuai dengan indikator/kriteria unjuk kerja yang telah ditentukan, Melaksanakan penilaian, Menganalisis hasil penilaian (berdasarkan tingkat kesukaran, daya pembeda, validitasi dan reliabilitas), Menyimpulkan hasil penilaian secara jelas dan logis (misalnya interpretasi kecenderungan hasil penilaian, tingkat pencapaian siswa), Menyusun laporan hasil penilaian, Memperbaiki soal/perangkat penilaian. Dimensi ini 
perlu dipertahankan dalam kinerja guru Madrasah Tsanawiyah Swasta pedesaan.

Oleh karena itu kecenderungan guru-guru Madrasah Tsanawiyah/MTs pedesaan yang ada di Kecamatan Tanjungsari belum membuat administrasi pembelajaran berupa Silabus, RPP, Daftar Hadir, Absensi, Program Tahunan, Program Semester dan lain-lain. Tetapi dilain pihak kecenderungan guru-guru Madrasah Tsanawiyah Swasta yang ada di pedesaan telah melaksanakan evaluasi hasil pembelajaran secara maksimal serta perlu ditingkatkan, termasuk dalam pelaksanaan tindak lanjut hasil evaluasi pembelajaran harus diperbaiki.

\section{Deskripsi Gaya Kepemimpinan Kepala Sekolah pada MTsS yang ada di Kecamatan Tanjungsari Kabupaten Sumedang}

Variabel gaya kepemimpinan kepala sekolah Marasah Tsanawiyah Swasta/MTsS yang ada di Kecamatan Tanjungsari adalah Sangat baik yaitu sebesar $88,65 \%$ dari seluruh pertanyaan pada variabel tersebut. Indikator dengan nilai persentase tertinggi ada pada item ke-1, yaitu Kepala sekolah selalu memperhatikan pada tugas pokok dan fungsi kerja guru. Persentase dari indikator ini sebesar $87,83 \%$. Sedangkan persentase terendah terdapat pada item ke-13, yaitu Kepala sekolah. Secara umum Gaya Kepemimpinan Kepala Sekolah Madrasah Tsanawiyah/MTsS baik yang ada di perkotaan maupun di pedesaan yang ada di Kecamatan Tanjungsari Kabupaten Sumedang, dalam dimensi Gaya Executive dengan indikatornya sebagai berikut: Menunjukan adanya perhatian baik kepada tugas maupun kepada hubungan kerja dalam kelompok. Pimpinan berusaha memotivasi anggota dan menetapkan standar kerja yang tinggi serta mau mengerti perbedaan individu dan menempatkan individu sebagai manusia. Gaya Developer dengan indikator sebagai berikut: Memberikan perhatian yang cukup tinggi terhadap hubungan kerja dalam kelompok dan perhatian minimum terhadap tugas pekerjaan. Pimpinan yang menganut gaya ini sangat memperhatikan pengembangan individu. Kedua dimensi tersebut mendapatkan nilai tertinngi yaitu dengan jumlah 489,2 atau nilai rata-ratanya 81,54\%. Sedangkan jumlah nilai terkecil yaitu dalam dimensi Gaya Kepemimpinan Birokrat sebanyak 481 atau nilai rata-ratanya $80,18 \%$. Dengan indikator sebagai berikut: Memberikan perhatian yang rendah terhadap tugas maupun terhadap hubungan. Pemimpin yang menganut gaya ini menerima setiap peraturan dan berusaha memeliharanya dan melaksanakannya.

Oleh karena itu Gaya Kepemimpinan Executive dan Developer Kecenderungan banyak dipakai dan perlu dipertahankan oleh para kepala sekolah, serta dimensi Gaya Kepemimpinan Birokrat perlu diperbaiki oleh para kepala sekolah Madrasah Tsanawiyah Swasta/MTsS baik yang ada di perkotaan maupun yang ada di pedesaan Kecamatan Tanjungsari Kabupaten Sumedang.

Variabel gaya kepemimpinan kepala sekolah Marasah Tsanawiyah Swasta/MTsS yang ada di Kecamatan Tanjungsari adalah Sangat baik yaitu sebesar 88,65 \% dari seluruh pertanyaan pada variabel tersebut. Indikator dengan nilai persentase tertinggi ada pada item ke-1, yaitu Kepala sekolah selalu memperhatikan pada tugas pokok dan fungsi kerja guru. Persentase dari indikator ini sebesar $87,83 \%$. Sedangkan persentase terendah terdapat pada item ke-13, yaitu Kepala sekolah. Dari data di atas secara umum Gaya Kepemimpinan Kepala Sekolah Madrasah Tsanawiyah/MTsS baik yang ada di perkotaan maupun di pedesaan yang ada di Kecamatan Tanjungsari Kabupaten Sumedang, dalam dimensi Gaya Executive dengan indikatornya sebagai berikut: Menunjukan adanya perhatian baik kepada tugas maupun kepada hubungan kerja dalam kelompok. Pimpinan berusaha memotivasi anggota dan menetapkan standar kerja yang tinggi serta mau mengerti perbedaan individu dan menempatkan individu sebagai manusia. Gaya Developer dengan indikator sebagai berikut: Memberikan perhatian yang cukup tinggi terhadap hubungan kerja dalam kelompok dan perhatian minimum terhadap tugas pekerjaan. Pimpinan yang menganut gaya ini sangat memperhatikan pengembangan individu. Kedua dimensi tersebut mendapatkan nilai tertinngi yaitu dengan jumlah 489,2 atau nilai rata-ratanya $81,54 \%$. Sedangkan jumlah nilai terkecil yaitu dalam dimensi Gaya Kepemimpinan Birokrat sebanyak 481 atau nilai rata-ratanya $80,18 \%$. Dengan indikator sebagai berikut: Memberikan perhatian yang rendah terhadap tugas maupun terhadap hubungan. Pemimpin yang menganut gaya ini menerima setiap peraturan dan berusaha memeliharanya dan melaksanakannya. 
Oleh karena itu gaya kepemimpinan executive dan developer kecenderungan banyak dipakai dan perlu dipertahankan oleh para kepala sekolah, serta dimensi gaya kepemimpinan birokrat perlu diperbaiki oleh para kepala sekolah Madrasah Tsanawiyah Swasta/MTsS baik yang ada di perkotaan maupun yang ada di pedesaan Kecamatan Tanjungsari Kabupaten Sumedang.

\section{Deskripsi Motivasi Kerja Guru pada MTsS yang ada di Kecamatan Tanjungsari Kabupaten Sumedang}

Variabel motivasi kerja guru Madrasah Tsanawiyah Swasta/MTsS yang ada di Kecamatan Tanjungsari adalah baik yaitu sebesar $80,35 \%$ dari seluruh pernyataan pada variabel tersebut. Indikator dengan nilai persentase tertinggi ada pada item ke-3, yaitu pemberian tunjangan profesi guru/tunjangan kinerja sangat membantu meningkatkan kesejahteraan. Persentase dari indikator ini sebesar 87.00. Sedangkan persentase terendah terdapat pada item ke-1, yaitu gaji yang diterima sesuai dengan beban kerja yang diemban, sebesar $73.5 \%$.

Motivasi kerja guru di Madrasah Tsanawiyah Swasta/MTsS pedesaan tertinggi yaitu nilai rata-rata $80,95 \%$, mungkin disebabkan oleh berbagai faktor seperti: Biaya hidup rendah, beras dan sayuran tersedia dengan harga murah serta terjangkau, dan lain sebagainya. Tetapi secara umum dimensi Motivasi Finansial mendapatkan nilai yang cukup tinngi yaitu dengan jumlah 363 atau nilai rata-rata $79,9 \%$. Oleh karena itu kecenderungan Motivasi Kerja Guru Madrasah Tsanawiyah Swasta/MTsS baik perkotaan maupun pedesaan yang ada di Kecamatan Tanjungsari Kabupaten Sumedang dipengaruhi oleh motivasi non finansial dan sangat didukung sekali oleh motivasi kerja guru yang bersifat finansial.

\section{Deskripsi Kinerja Guru pada MTsS yang ada di Kecamatan Tanjungsari Sumedang,}

Kinerja guru adalah baik yaitu sebesar $82,48 \%$ dari seluruh pernyataan pada variabel tersebut. Indikator dengan nilai persentase tertinggi ada pada item ke-10, Saya menyampaikan tujuan pembelajaran melalui media pembelajaran sesuai dengan cakupan materi yang akan dijelaskan, persentase sebesar $88.17 \%$. Hasil tersebut memberikan gambaran, bahwa guru menyampaikan tujuan pembelajaran melalui media pembelajaran sesuai dengan cakupan materi yang akan dijelaskan. Sedangkan persentase terendah terdapat pada item ke-28, yaitu pernyataan Saya jarang melaksanakan penilaian dengan berbagai teknik dan jenis penilaian, selain penilaian formal yang dilaksanakan sekolah, dan mengumumkan hasil serta implikasinya kepada peserta didik, tentang tingkat pemahaman terhadap materi pembelajaran yang telah dan akan dipelajari sesuai indikator, persentase sebesar 74.17.

Kinerja Guru Madrasah Tsanawiyah Swasta yang ada di perkotaan maupun pedesaan Kecamatan Tanjungsari Kabupaten Sumedang, dalam dimensi mengevaluasi hasil pembelajaran mendapatkan nilai rata-rata tertinngi yaitu dengan nilai rata-rata $84,7 \%$, dengan indikatornya sebagai berikut: Mengevaluasi hasil pembelajaran, Menyusun soal/perangkat penilaian sesuai dengan indikator/kriteria unjuk kerja yang telah ditentukan, Melaksanakan penilaian, Menganalisis hasil penilaian (berdasarkan tingkat kesukaran, daya pembeda, validitasi dan reliabilitas), Menyimpulkan hasil penilaian secara jelas dan logis (misalnya interpretasi kecenderungan hasil penilaian, tingkat pencapaian siswa), Menyusun laporan hasil penilaian, Memperbaiki soal/perangkat penilaian.

Sedangkan jumlah nilai rata-rata terkecil yaitu dalam dimensi tindak lanjut hasil pembelajaran sebesar 82,48 \%, dengan indikatornya sebagai berikut: Menyusun program tindak lanjut penilaian, Melaksanakan tindak lanjut, Mengevaluasi hasil tindak lanjut penilaian. Oleh karena itu Kecenderungan guru-guru Madrasah Tsanawiyah Swasta/MTsS di Kecamatan Tanjungsari mereka belum membuat administrasi pembelajaran berupa silabus, RPP, daftar hadir, absensi, program tahunan, program semester dan lain-lain. Tetapi dilain pihak kecenderungan guru-guru Madrasah Tsanawiyah Swasta/MTsS telah melaksanakan evaluasi hasil pembelajaran secara maksimal meskipun belum membuat administrasi perencanaan pembelajaran dengan baik dan benar, termasuk dalam pelaksanaan tindak lanjut hasil evaluasi pembelajarannya masih kurang dan perlu ditingkatkan.

\section{HASIL DAN PEMBAHASAN}

Pengaruh Gaya Kepemimpinan Kepala Sekolah Terhadap Motivasi Kerja 
Penelitian secara parsial dengan menggunakan rumus statistik hitung dengan program SPSS 20 menunjukan hasil tentang gaya kepemimpinan kepala sekolah memberikan pengaruh terhadap motivasi kerja. Hal ini dapat dilihat dari besarnya koefisien korelasi $(\mathrm{r})$ dari $\left(\mathrm{X}_{1}\right)$ gaya kepemimpinan kepala sekolah terhadap $\left(\mathrm{X}_{2}\right)$ Motivasi Kerja adalah sebesar 0,531. Artinya setiap peningkatan Gaya Kepemimpinan Kepala Sekolah sebesar 1 poin, maka motivasi kerja pun dapat ditingkatkan sebesar 0,531. Adapun besarnya pengaruh $\left(\mathrm{r}^{2}\right)$ $(0,531)^{2}=0.282$. Artinya variabel Gaya kepemimpinan Kepala Sekolah memberikan pengaruh nyata terhadap motivasi kerja sebesar $28,2 \%$. Adapun pengaruh variabel lain yang tidak diteliti terhadap variabel motivasi kerja (X2) adalah sebesar $71,8 \%$. Hal tersebut menunjukan bahwa pengaruh gaya kepemimpinan kepala sekolah lebih kecil daripada pengaruh variabel lain yang tidak diteliti.

Berdasarkan tabel koefisien diperoleh persamaan regresi X2 $=113,160+0,435 \mathrm{X} 1$. Persamaan ini dapat dipertanggungjawabkan (signifikan) karena nilai $\mathrm{p}<\alpha$ yaitu sebesar 0,115 . Pengujian Hipotesis pengaruh X1 terhadap X2. Berdasarkan tabel diketahui $t_{\text {hitung }}=1,771$. Adapun $t_{\text {tabel }}$ pada taraf signifikansi $5 \%$ dengan derajat kebebasan 8 adalah $=1,270$. Maka Ho ditolak dan Ha diterima. Artinya terdapat hubungan yang signifikan antara variabel $\mathrm{X} 1$ dan $\mathrm{Y}$ karena $\mathrm{t}_{\text {hitung }}>\mathrm{t}_{\text {tabel }}$. Adapun aplikasinya adalah sebesar 0,115 sehingga $\mathrm{Ha}$ diterima secara signifikan karena $\mathrm{p}<\alpha$. Gaya Kepemimpinan Kepala Sekolah berpengaruh secara signifikan terhadap Motivasi Kerja. Dengan demikian Hipotesis $\mathrm{H}_{1}$ diterima.

Berdasarkan hasil pengolahan data dan hasil penelitian ternyata terdapat pengaruh antara Gaya Kepemimpinan Kepala Sekolah terhadap Motivasi Kerja sebesar $28,2 \%$. Hal ini sangat logis karena Kepemimpinan Kepala Sekolah merupakan salah satu faktor adanya motivasi kerja.

\section{Pengaruh Gaya Kepemimpinan Kepala Sekolah Terhadap Kinerja Guru}

Penelitian secara parsial dengan menggunakan rumus statistik hitung dengan program SPSS 20 menunjukan hasil bahwa Gaya Kepemimpinan Kepala Sekolah Memberikan pengaruh terhadap kinerja guru. Hal ini dapat dilihat dari besarnya koefisien korelasi (r) dari $\left(\mathrm{X}_{1}\right)$ Gaya Kepemimpinan Kepala Sekolah terhadap (Y) Kinerja Guru adalah sebesar 0,173 . Artinya setiap peningkatan Gaya Kepemimpinan Kepala Sekolah sebesar 1 poin, maka kinerja guru pun dapat ditingkatkan sebesar 0,173 . Adapun besarnya pengaruh $\left(\mathrm{r}^{2}\right)(0,173)^{2}=$ 0.30 . Artinya variabel Gaya kepemimpinan Kepala Sekolah memberikan pengaruh nyata terhadap kinerja guru sebesar $30 \%$. Adapun pengaruh variabel lain yang tidak diteliti terhadap variabel kinerja guru (Y) adalah sebesar 70\%. Hal tersebut menunjukan bahwa pengaruh Gaya Kepemimpinan Kepala Sekolah lebih kecil daripada pengaruh variabel lain yang tidak diteliti.

Adapun linearitas pengaruh variabel X1 terhadap $\mathrm{Y}$ dapat dilihat berdasarkan Tabel diketahui $\mathrm{F}_{\text {hitung }}$ $=0,708, \mathrm{df}$ pembilang $=1$ dan $\mathrm{df}$ penyebut $=23$ sehingga diperoleh $\mathrm{F}_{\text {table }}$ pada taraf signifikansi $5 \%=$ 0,469 .ternyata $F$ hitung $>F$ table, maka antara variabel X1 dan Y bersifat linear. Berdasarkan nilai probabilitasnya diketahui $\mathrm{p}=0,409$. Maka linieritas variabel $\mathrm{X} 1$ dan $\mathrm{Y}$ signifikan karena $\mathrm{p}<\alpha$. Adapun persamaaan regresi antara variabel X1 dan $\mathrm{Y}$ dapat dilihat berdasarkan Tabel diperoleh persamaan regresi $\mathrm{Y}=95,732+0,171 \mathrm{X} 1$. Persamaan ini dapat dipertanggungjawabkan (Signifikan) karena nilai $\mathrm{p}<\alpha$ yaitu sebesar 0,409.

Pengujian Hipotesis pengaruh X1 terhadap Y. Berdasarkan tabel diketahui $t_{\text {hitung }}=0,842$. Adapun $\mathrm{t}_{\text {tabel }}$ pada taraf signifikansi $5 \%$ dengan derajat kebebasan 23 adalah 0,469. Maka Ho ditolak dan $\mathrm{Ha}$ diterima. Artinya terdapat hubungan yang signifikan antara variabel $\mathrm{X} 1$ dan $\mathrm{Y}$ karena $\mathrm{t}_{\text {hitung }}>$ $\mathrm{t}_{\text {tabel. }}$ Adapun aplikasinya adalah sebesar 0,409 sehingga Ha diterima secara signifikan karena $\mathrm{p}<\alpha$.

Berdasarkan Tabel dapat dipahami bahwa Gaya Kepemimpinan Kepala Sekolah berpengaruh secara signifikan terhadap kinerja guru. Dengan demikian Hipotesis $\mathrm{H}_{1}$ diterima.

Berdasarkan hasil pengolahan data dan hasil penelitian ternyata terdapat pengaruh antara Gaya Kepemimpinan Kepala Sekolah terhadap Kinerja Guru sebesar 30\%. Hal ini sangat logis karena Kepemimpinan Kepala Sekolah merupakan salah satu faktor adanya kinerja guru. 


\section{Pengaruh Motivasi Kerja terhadap Kinerja Guru}

Penelitian secara parsial dengan menggunakan rumus statistik hitung dengan program SPSS menunjukan hasil Motivasi Kerja memberikan pengaruh terhadap kinerja guru. Hal ini dapat dilihat dari besarnya koefisien korelasi (r) dari $\left(\mathrm{X}_{3}\right)$ dari variabel Motivasi kerja terhadap (Y) Kinerja guru adalah sebesar 0,250. Artinya setiap peningkatan motivasi kerja sebesar 1 poin, maka kinerja guru pun dapat ditingkatkan sebesar 0,250. Adapun besar pengaruhnya $\left(\mathrm{r}^{2}\right)$ adalah $(0.062)$

Artinya variabel motivasi kerja memberikan pengaruh nyata terhadap kinerja guru sebesar $0,62 \%$. Adapun pengaruh variabel lain yang tidak diteliti terhadap variabel kinerja guru (Y) adalah sebesar $38 \%$. Hal tersebut menunjukan bahwa pengaruh variabel motivasi kerja $\left(\mathrm{X}_{2}\right)$ lebih besar daripada pengaruh variabel lain yang tidak diteliti.

Adapun linearitas pengaruh variabel $\mathrm{X}_{2}$ terhadap $\mathrm{Y}$ dapat dilihat berdasarkan tabel di diketahui $\mathrm{F}_{\text {hitung }}=0,531$, df pembilang $=1$ dan $\mathrm{df}$ penyebut $=8$ sehingga diperoleh $\mathrm{F}_{\text {table }}$ pada taraf signifikansi 5\% = 0,498 ternyata $F_{\text {hitung }}>F_{\text {table }}$, maka linieritas variabel $\mathrm{X} 2$ dan $\mathrm{Y}$ Signifikan karena $\mathrm{P}<\alpha$.

Adapun persamaan regresi antara variabel $\mathrm{X}_{2}$ dan $\mathrm{Y}$ dapat dilihat berdasarkan tabel diperoleh persamaan regresi $\mathrm{Y}=98,452+0,219 \mathrm{X} 2$. Persamaan ini dapat dipertanggungjawabkan (signifikan) karena nilai $\mathrm{p}<\alpha$ yaitu sebesar 0,487. Pengujian Hipotesis pengaruh X2 terhadap Y, berdasarkan tabel diketahui $\mathrm{t}_{\text {hitung }}=0,729$. Adapun $\mathrm{t}_{\text {tabel }}$ pada taraf signifikansi $5 \%$ dengan derajat kebebasan 8 adalah 0,498. Maka Ho ditolak dan $\mathrm{Ha}$ diterima. Artinya terdapat hubungan yang signifikan antara Variabel X2 dan $\mathrm{Y}$ karena $\mathrm{t}$ hitung $>\mathrm{t}$ tabel. Adapun signifikansinya adalah sebesar 0,487 sehingga Ha diterima secara signifikan karena $\mathrm{P}<\alpha$.

Berdasarkan tabel dapat dipahami bahwa motivasi kerja berpengaruh secara signifikan terhadap kinerja guru. Dengan demikian hipotesis $\mathrm{H}_{1}$ diterima.

Berdasarkan hasil pengolahan data dan hasil penelitian ternyata terdapat pengaruh antara motivasi kerja terhadap kinerja guru sebesar 0,62. Maka dapat dikatakan bahwa semakin tinggi gaya kepemimpinan kepala sekolah maka akan semakin baik pula kinerja guru.

\section{Pengaruh Gaya Kepemimpinan Kepala Sekolah $\left(\mathbf{X}_{1}\right)$ dan Motivasi Kerja $\left(\mathbf{X}_{2}\right)$ terhadap Kinerja Guru (Y)}

Penelitian secara parsial dengan menggunakan rumus statistik yang penulis hitung dengan program SPSS menunjukan hasil ternyata gaya kepemimpinan kepala sekolah dan motivasi kerja memberikan pengaruh terhadap kinerja guru. Hal ini dapat dilihat dari besarnya koefisien korelasi (r) dari $\mathrm{X}_{1}$ dan $\mathrm{X}_{2}$ terhadap $\mathrm{Y}$ adalah sebesar 0,518. Artinya setiap peningkatan gaya kepemimpinan kepala sekolah dan motivasi kerja sebesar 1 poin, maka kinerja guru pun dapat ditingkatkan sebesar 0.518. Adapun besar pengaruhnya $\left(\mathrm{r}^{2}\right)$ adalah $(0.518)^{2}=$ 0.269 . Artinya variabel gaya kepemimpinan kepala sekolah dan motivasi kerja memberikan pengaruh nyata terhadap kinerja guru sebesar $26,9 \%$. Adapun pengaruh variabel yang tidak diteliti terhadap variabel kinerja guru (Y) adalah sebesar 70,1\%. Hal tersebut menunjukan bahwa pengaruh variabel gaya kepemimpinan kepala sekolah dan motivasi kerja lebih kecil daripada pengaruh variabel lain yang tidak diteliti.

Berdasarkan Tabel diketahui $\mathrm{F}_{\text {hitung }}=1,286$, df pembilang $=2$ dan $\mathrm{df}$ penyebut $=7$ sehingga diperoleh $\mathrm{f}_{\text {tabel }}$ pada taraf signifikansi $5 \%=0,766$ Ternyata $\mathrm{F}_{\text {hitung }}>\mathrm{F}_{\text {tabel }}$, maka antara variabel $\mathrm{X}_{1}$ dan $\mathrm{X}_{2}$ dan $\mathrm{Y}$ bersifat linear. Berdasarkan nilai probabilitas diketahui $\mathrm{p}=0,334$. Maka linearitas variabel $\mathrm{X} 1$ dan $\mathrm{X} 2$ dan $\mathrm{Y}$ signifikan karena $\mathrm{P}<\alpha$.

Adapun persamaan regresi antara variabel Gaya Kepemimpinan Kepala Sekolah $\left(\mathrm{X}_{1}\right)$, Variabel Motivasi Kerja $\left(\mathrm{X}_{2}\right)$ dan Variabel Kinerja Guru (Y) dapat dilihat pada Tabel diperoleh persamaan regresi $\mathrm{Y}=169,800+0,631 \mathrm{X}_{1}+0,468 \mathrm{X}_{2}$. Persamaan ini dapat dipertanggungjawabkan (signifikan) karena nilai $\mathrm{p}<\alpha$ yaitu sebesar 0,203 untuk $\mathrm{X}_{1}$ dan 0,204 untuk $\mathrm{X}_{2}$.

Dari Tabel tersebut dapat diketahui juga pengujian hipotess pengaruh X1 dan X2 terhadap Y. Berdasarkan tabel diketahui $\mathrm{t}_{\text {hitung }}=1,406$ untuk X1 dan 1,400 untuk X2. Adapun $t_{\text {table pada taraf }}$ signifikansi 5\% dengan derajat kebebasan 7 adalah 0,766. Maka Ho ditolak dan Ha diterima. Artinya terdapat hubungan yang signifikan antara variabel X1 dan X2 terhadap Y karena $t_{\text {hitung }}>t_{\text {table }}$. Adapun signifikansinya adalah sebesar 0,203 
untuk X1 dan 0,204 untuk X2 sehingga Ha diterima secara signifikan karena $\mathrm{p}<\alpha$.

Berdasarkan $\mathrm{T}$ tabel dapat dipahami bahwa variabel gaya kepemimpinan kepala sekolah, motivasi kerja secara simultan berpengaruh positif dan signifikan terhadap kinerja guru, Dengan demikian hipotesis Ha diterima.

Berdasarkan hasil pengolahan data dan hasil penelitian ternyata terdapat pengaruh antara Gaya Kepemimpinan Kepala Sekolah dan Motivasi Kerja terhadap Kinerja Guru Sebesar 26,9\%. Maka dapat dikatakan bahwa semakin baik kualitas gaya kepemimpinan Kepala Sekolah dan Motivasi Kerja maka akan semakin baik pula kinerja guru.

Upaya-upaya manajerial yang dilakukan untuk meningkatkan kinerja guru melalui perbaikan gaya kepemimpinan kepala sekolah dan motivasi kerja guru Madrasah Tsanawiyah/MTsS yang ada di Kecamatan Tanjungsari Kabupaten Sumedang.

Berdasarkan hasil analisis dan pembahasan sebelumnya, maka upaya-upaya yang harus dilakukan untuk meningkatkan kinerja guru pada Madrasah Tsanawiyah Swasta/MTsS baik yang ada di perkotaan maupun di pedesaan Kecamatan Tanjungsari Kabupaten Sumedang, yaitu:

1) Upaya untuk meningkatkan gaya kepemimpinan seorang kepala sekolah yaitu dengan cara meningkatkan dimensi-dimensi yang menentukan variabel tersebut, antara lain:

a) Meningkatkan dimensi gaya executif dan developer, meskipun kecenderungan banyak dipakai oleh para kepala sekolah Madrasah Tsanawiyah Swasta/MTsS baik di perkotaan maupun pedesaan yang ada di Kecamatan Tanjungsari Kabupaten Sumedang gaya Executive, meliputi: Perhatian tinggi pada tugas dan hubungan kerja, memotivasi kerja guru, menetapkan standar kerja yang tinggi, memperhatikan perbedaan individu dan menggunakan kerja tim. Sedangkan gaya Developer meliputi: Perhatian tinggi pada hubungan kerja dan perhatian rendah pada tugas, Menaruh kepercayaan pada bawahan, Memperhatikan pengembangan karyawan. Karena skor penilaian responden masih dinilai $81,54 \%$ kriteria penilaian baik, agar dapat ditingkatkan menjadi lebih baik atau sangat baik.

b) Meningkatkan dimensi gaya birokrat meskipun kecenderungan memiliki jumlah nilai terkecil, meliputi: Perhatian rendah pada tugas maupun pada hubungan kerja, Menggunakan peraturan dalam setiap langkah, melakukan pengawasan secara teliti. Karena skor penilaian responden masih dinilai $80,18 \%$ kriteria penilaian baik, agar dapat ditingkatkan menjadi lebih baik atau sangat baik.

c) Meningkatkan gaya Benevolent Authocrat yang meliputi: Perhatian penuh pada tugas dan perhatian rendah pada hubungan kerja, pengambilan keputusan secara cepat sesuai prosedur dan kepercayaan diri tinggi. Karena skor penilaian responden masih dinilai 80,79\% kriteria penilaian baik, agar dapat ditingkatkan menjadi lebih baik atau sangat baik.

2) Upaya untuk meningkatkan motivasi kerja guru, yaitu dengan cara meningkatkan dimensidimensi yang menentukan variabel tersebut, antara lain:

a) Meningkatkan motivasi finansial untuk guru Madrasah Tsanawiyah baik yang ada di perkotaan maupun yang ada di pedesaan, meliputi: Gaji, tunjangan keluarga, tunjangan fungsional, upah lembur, uang pembinaan, tunjangan hari raya. Karena skor penilaian responden secara umum masih dinilai 79,9\% kriteria penilaian baik, agar dapat ditingkatkan menjadi lebih baik atau sangat baik.

b) Meningkatkan motivasi non finansial untuk guru Madrasah Tsanawiyah Swasta/MTsS baik yang ada di pekotaan maupun pedesaan, meliputi: Kenaikan pangkat, tanda penghargaan, pendidikan dan pelatihan, promosi jabatan. Meskipun mendapatkan skor penilaian responden masih tertinggi $81 \%$ kriteria penilaian baik, namun masih harus ditingkatkan menjadi lebih baik atau sangat baik. 
3) Upaya untuk meningkatkan kinerja guru, yaitu dengan cara meningkatkan dimensi-dimensi yang menentukan variabel tersebut, antara lain:

a) Meningkatkan perencanaan pembelajaran bagi guru Madrasah Tsanawiyah/ MTsS ,melalui forum MGMP, Diklat Kurikulum dan sebagainya. Meliputi: Membuat perangkat pembelajaran, menentukan materi sesuai dengan kompetensi yang telah ditentukan, menentukan metode pembelajaran yang sesuai materi pembelajara menentukan media pembelajaran. Skor penilaian responden dengan nilai $82,68 \%$ kriteria penilaian baik, agar dapat ditingkatkan menjadi lebih baik atau sangat baik.

b) Meningkatkan pelaksanaan kegiatan pembelajaran yang meliputi: Kegiatan pendahuluan, kegiatan inti, dan kegiatan penutup. Karena skor penilaian responden masih dinilai 82,5 kriteria penilaian baik, agar dapat ditingkatkan menjadi lebih baik atau sangat baik.

c) Meningkatkan cara evaluasi hasil pembelajaran baik guru Madrasah Tsanawiyah perkotaan maupun pedesaan, yang dilaksanakan melalui MGMP, Diklat Kurikulum, dan lain sebagainya. Meliputi: Menyusun soal/perangkat penilaian sesuai dengan indikator/kriteria unjuk kerja yang telah ditentukan, melaksanakan penilaian, menganalisis hasil penilaian (berdasarkan tingkat kesukaran, daya pembeda, validasi dan reliabilitas), menyimpulkan hasil penilaian secara jelas dan logis (misalnya interpretasi kecenderungan hasil penilaian, tingkat pencapaian siswa), menyusun laporan hasil penilaian, memperbaiki soal/perangkat penilaian. Meskipun skor penilaian responden sangat baik $84,7 \%$,agar dapat ditingkatkan menjadi sangat lebih baik atau minimal bertahan sangat baik.

d) Meningkatkan tindak lanjut hasil penilaian prestasi belajar untuk guru Madrasah Tsanawiyah Swasta/MTsS baik yang ada diperkotaan maupun di pedasaan yang ada di Kecamatan Tanjungsari Kabupaten Sumedang melalui: Forum MGMP, Diklat
Kurikulum, Tutor Teman Sejawat mata pelajaran. Dalam pelaksanaannya meliputi: Menyusun tindak lanjut penilaian pembelajaran, melaksanakan tindak lanjut penilaian, mengevaluasi hasil tindak lanjut penilaian. Meskipun skor penilaian responden masih rendah dengan nilai rata-rata 82,48 kriteria penilaian baik, agar dapat ditingkatkan menjadi lebih baik atau sangat baik.

Selain upaya-upaya di atas, dalam upaya manajerial yang dilakukan untuk meningkatkan kinerja guru melalui perbaikan gaya kepemimpinan kepala sekolah dan motivasi kerja guru Madrasah Tsanawiyah Swasta/MTsS baik yang ada di perkotaan maupun di pedesaan Kecamatan Tanjungsari Kabupaten Sumedang, yaitu melaksanakan manajerial yang menggunakan analisis SWOT. (strength/kekuatan, weakness/ kelemahan, opportunities/kesempatan dan threats/ ancaman. Sebagaimana yang di jelaskan oleh Karna Sobahi dan kawan-kawan (2010: 23). Secara mudah analisis SWOT bisa dikelompokkan dalam dua kategori, yaitu: 1). Internal Lembaga, yang menyangkut strength dan weakness. dengan mempertimbangkan pada: sarana dan prasarana, kumpulan pendapat, komparasi dengan lembaga lain dan hasil pengamatan sendiri. Serta memperhatikan obyek analisisnya yang meliputi: kemampuan memimpin, jumlah dan kualitas anggota, kerapihan organisasi (termasuk struktur, AD/ART, serta kebijakan-kebijakan) dan aturan kedisiplinan. 2). Eksternal Lembaga yang menyangkut Opportunities dan Threats, dengan mempertimbangkan pada: Pengalaman kita sendiri, kumpulan pendapat, komparasi dengan lembaga lain dan menurut pendapat para ahli/pakar. Serta memperhatikan obyek analisisnya yang meliputi: Personal atau lembaga yang tengah berkuasa, kebijakan-kebijakan yang dikeluarkan serta kejadian-kejadian atau peristiwa penting yang pernah terjadi.

Proses penggunaan manajemen analisis SWOT menghendaki adanya suatu survei internal tentang strength (kekuatan) dan weakness (kelemahan) program, serta survei eksternal atas opportunities (ancaman) dan threats (peluang/kesempatan). Pengujian eksternal dan internal yang terstruktur adalah sesuatu yang unik dalam perencanaan dan pengembangan kurikulum lembaga pendidikan termasuk Madrasah Tsanawiyah/MTs. 


\section{KESIMPULAN DAN SARAN}

\section{Kesimpulan}

(1) Terdapat pengaruh yang positif dan signifikan antara gaya kepemimpinan kepala sekolah dengan empat sub-variabel terutama Gaya Executive dan Gaya Developer

(2) Terdapat pengaruh yang positif dan signifikan antara gaya kepemimpinan kepala sekolah terhadap kinerja guru pada Madrasah Tsanawiyah/MTs

(3) Terdapat pengaruh yang positif dan signifikan antara motivasi kerja terhadap kinerja guru, terutama motivasi finansial.

(4) Terdapat pengaruh yang positif dan signifikan antara gaya kepemimpinan kepala sekolah dan motivasi kerja secara bersama-sama terhadap kinerja guru.

(5) Upaya-upaya manajerial untuk memperbaiki gaya kepemimpinan kepala sekolah dan motivasi kerja serta kinerja guru yaitu dengan cara meningkatkan dimensi-dimensi yang menentukan variabel tersebut.

\section{Saran}

(1) Meningkatkan dimensi gaya executif dan developer, gaya birokrat, dan gaya Benevolent Authocrat meskipun kecenderungan banyak dipakai oleh para kepala sekolah Madrasah Tsanawiyah Swasta/MTsS baik di perkotaan maupun pedesaan

(2) Meningkatkan motivasi finansial untuk guru Madrasah Tsanawiyah baik yang ada di perkotaan maupun yang ada di pedesaan,

(3) Meningkatkan perencanaan pembelajaran dan non pembelajaran bagi guru Madrasah Tsanawiyah/ MTsS ,melalui forum MGMP, Diklat Kurikulum dan sebagainya.

(4) Selain upaya-upaya di atas, dalam upaya manajerial yang dilakukan untuk meningkatkan kinerja guru melalui perbaikan gaya kepemimpinan kepala sekolah dan motivasi kerja guru Madrasah Tsanawiyah Swasta/ MTsS baik yang ada di perkotaan maupun di pedesaan, yaitu melaksanakan manajerial yang menggunakan analisis SWOT

\section{DAFTAR PUSTAKA}

Ahmad Tafsir, (1996). Pendidikan Agama dalam Keluarga. Bandung: Remaja Rosda.

Budimansyah Dasyim. (2002) Model Pembelajaran dan Penilaian Portofolio. Bandung: Al Gesindo.

Dadi Permadi. (2001). Manajeman Berbasis Sekolah dan Kepemimpinan Mandiri Kepala Sekolah. Bandung: Sarana Panca Karya.

Depdiknas. (2005). Undang-Undang Republik Indonesia, Nomor: 14 Tahun 2005 tentang Guru dan Dosen. Bandung: Fokus Media.

E. Mulyasa. (2003). Menjadi Kepala Sekolah dalam Konteks Mensukseskan MBS dan KBK. Bandung: Remaja Rosdakarya.

(2005). Manajemen Berbasis Sekolah. Bandung: PT. Remaja Rosda Karya.

(2011). Menjadi Kepala Sekolah Profesional. Bandung. Rosda Karya.

Gito Sudarmo, Indriyo \& Agus Mulyono, (1999), Prinsip dasar manajemen, Yogyakarta: BPFE.

Hasibuan, Malayu S.P. (2003). Majemen: Dasar, Pengertian, dan Masalah. Jakarta: Bumi Aksara.

M.Sobry Sutikno. (2010). Pengelolaan Pendidikan, Tinjauan umum dan konsep Islami, Bandung: Prospect.

Ngalim Purwanto, (2002). Administrasi dan Supervisi Pendidikan. Bandung: PT. Remaja Rosda Karya.

Syaiful Sagala. (2008). Memehami organisasi Pendidikan (Pemberdayaan Organisasi Pendidikan yang lebih Profesional dan Dinamis dari Aspek Desain, Budaya, Reinventing di Provinsi, Kabupaten/Kota dan Satuan Pendidikan. Bandung: Alfabeta.

S. Nasution. (2004). Didaktik Asas-Asas Mengajar, Jakarta: Bumi Aksara.

Siagian, Sondang P. (2004). Teori Motivasi dan Aplikasinya. Jakarta; PT. Rineka Cipta. 
Wahyudi. (2009). Kepemimpinan Kepala Sekolah Dalam Organisasi Pembelajaran (Learning Organization). Pontianak: Alfabeta.

Wahjosumidjo. (2005). Kepemimpinan Kepala Sekolah, Jakarta: Raja Grafindo Persada.

Wibowo. (2011). Manajemen Kinerja. Jakarta: Rajawali Pers.

Yunus, (2007). Kepemimpinan Pendidikan. Ciamis: Unigals. 